\title{
Meta
}

Journal des traducteurs

Translators' Journal

\section{Interjections in Original and Dubbed Sitcoms in Catalan: A Comparison}

\section{Anna Matamala}

Volume 54, numéro 3, septembre 2009

URI : https://id.erudit.org/iderudit/038310ar

DOI : https://doi.org/10.7202/038310ar

Aller au sommaire du numéro

Éditeur(s)

Les Presses de l'Université de Montréal

ISSN

0026-0452 (imprimé)

1492-1421 (numérique)

Découvrir la revue

Citer cet article

Matamala, A. (2009). Interjections in Original and Dubbed Sitcoms in Catalan: A Comparison. Meta, 54(3), 485-502. https://doi.org/10.7202/038310ar
Résumé de l'article

Le présent article fait état d'une analyse des interjections, lesquelles constituent des éléments très spécifiques de la communication orale, dans un corpus composé de comédies de situation doublées ou enregistrées d'emblée en catalan. La notion d'interjection et les caractéristiques du corpus sont tout d'abord définies. Le nombre d'interjections figurant dans chacun des deux sous-corpus fait l'objet d'une comparaison, et le pourcentage d'occurrences est également comparé au pourcentage d'interjections présentes dans un corpus de conversations réelles spontanées en catalan. Les possibles effets des contraintes du doublage sur l'oralité dans les productions doublées sont discutés et les changements subis par les interjections au cours de ce processus dynamique sont mis en évidence. 


\title{
Interjections in Original and Dubbed Sitcoms in Catalan: A Comparison
}

\author{
ANNA MATAMALA \\ Universitat Autònoma de Barcelona, Barcelona, Spain \\ anna.matamala@uab.cat
}

\begin{abstract}
RÉSUMÉ
Le présent article fait état d'une analyse des interjections, lesquelles constituent des éléments très spécifiques de la communication orale, dans un corpus composé de comédies de situation doublées ou enregistrées d'emblée en catalan. La notion d'interjection et les caractéristiques du corpus sont tout d'abord définies. Le nombre d'interjections figurant dans chacun des deux sous-corpus fait l'objet d'une comparaison, et le pourcentage d'occurrences est également comparé au pourcentage d'interjections présentes dans un corpus de conversations réelles spontanées en catalan. Les possibles effets des contraintes du doublage sur l'oralité dans les productions doublées sont discutés et les changements subis par les interjections au cours de ce processus dynamique sont mis en évidence.
\end{abstract}

\begin{abstract}
This article analyses interjections, a very specific element of orality, in a corpus of sitcoms both dubbed into Catalan and originally shot in Catalan. After defining interjections and describing the corpus used to carry out the analysis, a comparison between the number of interjections contained in the dubbed sitcoms of the corpus and the number of interjections included in those originally shot in Catalan is presented. This data is also compared to the percentage of interjections found in a corpus of real spontaneous conversations in Catalan. Finally, the possible effects of the constraints of dubbing on the orality of dubbed products are discussed and the changes interjections undergo during this dynamic process are highlighted.
\end{abstract}

\section{MOTS-CLÉS/KEYWORDS}

doublage, interjections, oralité, comédie de situation, catalan dubbing, interjections, orality, sitcoms, Catalan

\section{Introduction}

Various researchers have dealt with the topic of orality in audiovisual translations, highlighting that the language of dubbing is a simulated orality which does not include all the features of real oral spontaneous language (Chaume 2003: 213-221; Chiaro 2005). This article presents an analysis of one marker of orality - interjections - in a corpus of sitcoms either dubbed into Catalan or originally shot in Catalan (Matamala 2005a).

First, the items included under the category interjections will be defined. Second, the corpus used to carry out the analysis will be described and, third, the results of the comparison between the number of interjections contained in the dubbed sitcoms of the corpus and the number of interjections included in those originally shot in Catalan will be presented. This data will also be compared to the percentage of interjections found in a corpus of real spontaneous conversations in 
Catalan, a comparison which will help to attribute different degrees of orality to different products. Finally, the possible effects of the constraints of dubbing on the orality of dubbed products will be discussed. ${ }^{1}$

\section{Defining interjections: a cognitive-based approach}

A definition of the category "interjection" has not yet been clearly established: in traditional grammars interjections are usually included among word classes and stress is placed on their phonological anomalies, syntactic independence, morphological invariance and expressive nature (Crystal and Quirk 1985; Greenbaum and Quirk 1990; Huddleston 1986; Leech and Svartvik 1975; Quirk et al. 1972). Some of these units have also been studied from other perspectives and labelled phraseological units (Lorente 2002; Sancho 1999), discourse markers (Aijmer 2002; Andersen 2001; Brinton 1996; Fischer 2000; Fraser 1990; 1999; Redeker 1990; Schiffrin 1987; Schourup 1982), vocalizations and paralinguistic features (Calsamiglia and Tusón 1999; Kerbrat-Orecchioni 1990; 1996; Crystal and Quirk 1964; Trager 1958), response cries (Goffman 1981) or even alternants (Poyatos 1993). They are even the main topic of certain monographic articles and theses (Ameka 1992; James 1973; Wilkins 1992; Wierzbicka 1992). However, each of these theoretical frameworks pays attention to specific subcategories of interjections, with analyses focusing on a number of characteristics from various points of view.

The objective of this study is also to provide an extensive analysis of linguistic elements that may be included in the category of interjections. To this end, Cuenca's cognitive model $(1996 ; 2000 ; 2002 a)$ has proven to be the most appropriate because the definition of interjections is based on the prototype theory (Kleiber 1990; Taylor 1989; Ungerer and Schmid 1996) as well as on the theory of grammaticalization (Hopper and Traugott 2003; Lehmann 1995; Traugott and Heine 1991). As a result, the definition includes a wide array of units under a single category.

According to the prototype theory, interjections are considered to form a peripheral class of the category "sentence." They correspond to communicative units that are syntactically autonomous as well as intonationally and semantically complete (Cuenca 2000; 2002a). Furthermore, they generally express pragmatic values, but they do not consist of a subject associated to a predicate and are highly context dependent.

The theory of grammaticalization accounts for the evolution of secondary interjections through a process of subjectification (Traugott 1995). This cognitive-based approach considers that boundaries are fuzzy and that members of a category may share only a small number of attributes with other members of the same category. This allows, under the heading "interjections", the inclusion of items such as $\mathrm{mhm}$ or tut (which, according to certain authors [Poyatos 1993], constitute paralinguistic features), together with prototypical interjections such as oh or ah and even almost phraseological expressions such as damn or holy shit. The units which have a simple form and do not come from another word class are called "primary interjections" (oh, ah, ouch), whereas those that come from another word class and have become interjections through a process of grammaticalization are called "secondary interjections" (God, bloody hell, shit).

As shown in Matamala (2005b), interjections play a key role in the three main elements of a conversation, accomplishing different functions in openings, develop- 
ments and closings (Tusón 1995). As defined and exemplified below, Cuenca, adapting Jakobson's classical functions, proposes differentiating expressive, conative, phatic, metalinguistic and representative interjections.

\subsection{Expressive interjections}

Expressive interjections express the speaker's feelings, for example, Good God or wow.

(1) Hal: Your wife wants to know if you've looked at the carpet satches, your gardener wants to know if he should re-seed your lawn, and your mother's cancer specialist needs to know about her living will.

Matt: Good God, woman, you didn't call me in the car about this? How much time did he say is left? Hal: Two weeks until rainy season.

(“Working," episode 21)

(2) Matt: I propose a four day working week in which employees would work Monday through Thursday for ten hours a day, adding an hour in the morning and an hour in the afternoon.

Hal: Wow, Matt, it must feel terrific to see one of your ideas put into action.

("Working," episode 21)

\subsection{Conative interjections}

Conative interjections are units used by the speaker in order to produce an effect on the listener, such as please or hey!

(1) Abby: I want to hear it, Matt. What's your idea? Tell me, tell me.

Matt: Well, I came up with it in the shower this morning.

Abby: Uh. Please, tell me. Tell me.

("Working," episode 21)

(2) Hal: Well, if this is your way of apologizing for all of your demeaning derogatory remarks then I say, "apology accepted." Hey! Look everybody. Delaney gave me flowers.

(“Working," episode 21)

\subsection{Phatic interjections}

Phatic interjections show that communication has been established. Two subtypes can be found. The first contains prototypical units like good morning, hello, bye or thanks. The second are units between phatic and metalinguistic interjections, expressing agreement, disagreement, etc., such as allright, fine or OK.

(1) Butch: Who goes on a date on Thanksgiving?

Pamela: Popular people.

Butch: Fine. I'll just take this over to Mom and Dad's for dinner. They're not popular.

("Normal, Ohio," episode 2)

(2) Pamela: Forget it. I'm not doing Thanksgiving.

Butch: For Tom? C'mon, do you realize how old Mom and Dad are? This could be our last Thanksgiving together.

Pamela: All right, all right, I'll do it. For Tom. Robbie! Kimberly! Bad news! We're having Thanksgiving together! 


\subsection{Metalinguistic interjections}

Metalinguistic interjections are used as discourse markers (Schiffrin 1987). They are the key elements which demarcate units of speech in conversational exchanges, e.g. look, well or listen.

(1) Abby: I want to hear it, Matt. What's your idea? Tell me, tell me. Matt: Well, I came up with it in the shower this morning.

(“Working," episode 21)

(2) Pamela: You're not going to that game!

Pamela: Look, sis, this is my son, who I haven't seen in four years, who wants to share something special with me. Let me bond with my son.

("Normal, Ohio," episode 2)

\subsection{Representative interjections}

Finally, representative interjections are onomatopoeic interjections such as miaow, gobble, gobble or cock-a-doodle-doo.

(1) Joan: Gobble, gobble. We're here. (Imitating a turkey's sound).

("Normal, Ohio," episode 2)

\section{Audiovisual corpus of sitcoms}

The audiovisual corpus of sitcoms was created in 2002 and contains two subcorpora: a monolingual subcorpus (Table 1) and a bilingual subcorpus (Table 2). ${ }^{2}$ The first includes 25-minute sitcoms originally shot in Catalan and broadcast on Catalan television with great success: episodes 2 and 3 of the series Plats Bruts, and episodes 1 and 2 of Jet Lag. Both series display a very oral language and the selection of the episodes was based on the availability of the material. The subcorpus includes the transcription of the final broadcast version (which does not always correspond to the script given to actors) aligned with audiovisual clips. The segmentation of the clips was carried out with Videosplitter, a freeware software, and the alignment was done manually due to the absence of adequate software.

TABLE 1

Monolingual subcorpus (number of words)

\begin{tabular}{|l|c|}
\hline Series & Catalan \\
\hline Jet Lag, episode 1 & 3,931 words \\
\hline Jet Lag, episode 2 & 3,394 words \\
\hline Plats bruts, episode 2 & 3,092 words \\
\hline Plats bruts, episode 3 & 4,414 words \\
\hline Total & 18,222 words \\
\hline
\end{tabular}

The bilingual subcorpus consists of British and American sitcoms, both in the original version and in the Catalan dubbed version. The sample was randomly selected and consisted of one episode of the British sitcom Coupling (Parelles), one episode of the American sitcom Working (Jornada Intensiva) and one episode of the American sitcom Normal, Ohio (Normal, Ohio), all broadcast on Catalan television. Again the 
availability of scripts and video material was paramount in the process. The alignment text-video was also manually carried out, but a specific software developed at the Institut Universitari de Lingüística Aplicada (Universitat Pompeu Fabra-Barcelona) (De Yzaguirre et al. 2005) was used to align both written transcriptions.

TABLE 2

Bilingual corpus (number of words in the broadcast version)

\begin{tabular}{|l|c|c|}
\hline Series & Catalan & British/American \\
\hline Coupling/Parelles & 3,698 words & 3,727 words \\
\hline Working/Jornada Intensiva & 2,605 words & 2,726 words \\
\hline Normal, Ohio & 2,919 words & 3,045 words \\
\hline Total & 9,222 words & 9,498 words \\
\hline
\end{tabular}

The whole corpus, that has been used to carry out the study, contains a remarkably high number of interjection occurrences (Table 3).

TABLE 3

Number of occurrences of interjections

\begin{tabular}{|l|c|}
\hline Corpus & N \\
\hline Catalan (original) & 882 \\
\hline Catalan (dubbed) & 296 \\
\hline English & 362 \\
\hline
\end{tabular}

\section{Comparing interjections in original and dubbed sitcoms}

Interjections are commonly found in spontaneous conversations. However, sitcoms are nothing but fiction attempting to imitate spontaneous oral dialogue with certain time restrictions. This forces scriptwriters to mimic oral features only to a certain degree so that the action may go on. This section deals with two questions: to what extent the dialogues found in sitcoms differ from real spontaneous conversations? And to what extent the actors oralise the script? Due to their relevance to the oral language, interjections are used as a marker to answer these questions. Needless to say, other units than interjections should be considered in order to reach valid conclusions concerning the spontaneity of these audiovisual products, but the analysis of interjections may be considered as a first step shedding light on this issue. Hence, the number of interjections have been counted in: (1) the written script given to the actors; (2) the final broadcast version; and (3) spontaneous conversations. Then the rate of interjections in relation to the total number of tokens in each corpus was calculated (Table 4).

For spontaneous conversations, the data obtained by Castellà (2004) were used. Castellà used the same cognitive-based framework as Cuenca's and the corpus consisted of a 27,254-word sample from the Corpus Oral de Conversa Colloquial (COC; Oral Corpus of Colloquial Conversations) from the Corpus del Català Contemporani (Catalan Contemporary Corpus) from the Universitat de Barcelona (Payrató and Alturo 2002). 
TABLE 4

Number and rate of interjections

\begin{tabular}{|l|c|c|c|c|}
\hline & \multicolumn{2}{|c|}{ Catalan } & \multicolumn{2}{c|}{ Dubbed } \\
& N & \% & N & \% \\
\hline Written script & 349 & $3.01 \%$ & 295 & $3.03 \%$ \\
\hline Broadcast sitcom & 882 & $4.84 \%$ & 296 & $3.2 \%$ \\
\hline Spontaneous language & 1,387 & $5.09 \%$ & - & - \\
\hline
\end{tabular}

The following sections present a detailed analysis of these results.

\subsection{Interjections in Catalan sitcoms}

In the Catalan sitcoms, actors add a remarkably high number of interjections which are not found in the original script, which contains 11,594 words. From the 349 interjections originally found in the written pre-production script (3.01\%), 66 are eliminated by the actors and 601 new interjections are added, reaching a total of $882(4.84 \%$ due to the fact that the final broadcast version contains 18,222 words, a remarkably higher number due to improvisations which are not present in the script). The proportion of interjections in the broadcast sitcom is therefore more similar to the $5.09 \%$ of interjections found in a corpus of real spontaneous Catalan conversations made up of 27,254 words. Therefore, the higher proportion of interjections in Catalan original sitcoms suggests that they show a high degree of orality, as they perfectly simulate spontaneity, thanks to the improvisations of the actors, a hypothesis that Martí (1997: 75) had already proposed when analysing the language of Catalan fiction series. Some of the interjections which result from improvisation in the Catalan original corpus are shown in Table 5, next to their approximate meaning.

TABLE 5

Interjections added in the Catalan original corpus

\begin{tabular}{|l|c|l|}
\hline & $\begin{array}{l}\text { Number of added } \\
\text { occurrences }\end{array}$ & Meaning and similar English interjections \\
\hline Aaa & 13 & Interjection expressing doubt (er) \\
\hline $\mathrm{Ah}$ & 54 & Multipurpose interjection (oh) \\
\hline $\mathrm{Ai}$ & 43 & $\begin{array}{l}\text { Multipurpose interjection expressing both pain (ouch) and } \\
\text { sudden realisation (oh) }\end{array}$ \\
\hline Bueno & 27 & $\begin{array}{l}\text { Widely used interjection meaning well but not included in } \\
\text { the normative dictionary. }\end{array}$ \\
\hline Eh? & 107 & Interjection meaning approximately right?, ok?, huh? \\
\hline Ei & 26 & Interjection meaning hey. \\
\hline Escolta/eu & 18 & Interjection used at the beginning of a sentence (listen) \\
\hline Home & 34 & $\begin{array}{l}\text { Multipurpose interjection with a wide range of meanings } \\
\text { (literally: man) }\end{array}$ \\
\hline Mira & 25 & Interjection used at the beginning of a sentence (look) \\
\hline Mmm & 31 & $\begin{array}{l}\text { Primary interjection with different meanings according to } \\
\text { the intonation. }\end{array}$ \\
\hline Molt bé & 10 & $\begin{array}{l}\text { Generally used at the beginning of sentences, literally } \\
\text { meaning very well (OK). }\end{array}$ \\
\hline No? & 16 & Question tag. \\
\hline Oh & 18 & Multipurpose interjection (oh) \\
\hline Va & 21 & Conative interjection (come on) \\
\hline Vale & 17 & $\begin{array}{l}\text { Widely used interjection meaning OK but not included in } \\
\text { the normative dictionary. }\end{array}$ \\
\hline
\end{tabular}


This data also demonstrate what Paloma and Segarra (2000: 54) had already stated: although the script is always planned and has been revised by a registered linguist, actors oralise the text and include oral and colloquial features, sometimes distancing themselves from the linguistic norm. In our corpus, some of the interjections resulting from actor improvisation are not sanctioned by the prescriptive authorities (Institut d'Estudis Catalans): interjections such as bueno or vale, calques from their Spanish counterparts, find their way into Catalan sitcoms because actors include them spontaneously, whereas in dubbing these units are never found due to the strict linguistic revision undergone by all products (see section 5). There is no doubt that, in terms of language control, a laxer approach is adopted towards programmes originally produced in Catalan, especially those aimed at a young audience, and the medium gives actors the freedom to include improvised sentences and interjections, mirroring oral colloquial language. For instance, in colloquial texts, the unit bueno is more commonly used than the normative bé (Espuny 1998, González 1998, Vila 1998) and even carries an expressive and illocutive force not found in bé (González 2001). As far as vale is concerned, it is also one of the Spanish loanwords most commonly found in Catalan (Vila 1998), but unluckily there are no specific studies that have addressed this unit.

\subsection{Interjections in dubbed sitcoms}

Dubbed sitcoms contain approximately the same number of interjections in the written script (295 interjection in a 9,735-word corpus, that is 3.03\%) as in the broadcast version (296 interjections in a 9,222-word corpus, that is $3.2 \%$ ). This moves away from the percentage of real spontaneous language in Catalan (5.09\%) and demonstrates that dubbing leaves virtually no room for improvisations, an issue further developed in section 5. Considering the fact that dubbed scripts contain a lower percentage of interjections, a key question arises: do translators omit interjections when translating from English into Catalan or does the English version contain a limited number of interjections? In our corpus, the English version contains 3.81\% of interjections - 362 interjections in a 9,498-word corpus - a higher percentage compared to the final dubbed product but low compared to Catalan spontaneous interjections. ${ }^{3}$

\section{Dubbing constraints}

As demonstrated in the previous section, dubbed versions present a limited number of changes as far as interjections are concerned, contrary to the differences observed between the written script and the broadcast version in Catalan sitcoms. The second part of the article is intended to demonstrate that dubbing is, however, a dynamic process in which changes occur, particularly in the first stages (from the draft translation to the final written version) and much less frequently in the last stages (recording), with actors refraining from oralising the script.

As shown in Figure 1, dubbing in Catalonia is a long process which involves different agents. I will focus on the highlighted tasks (translation, adaptation and linguistic revision), which can be carried out by a single professional or different professionals. 
FigURE 1

Dubbing process in Catalonia (adapted from Ledesma and López, 2002)

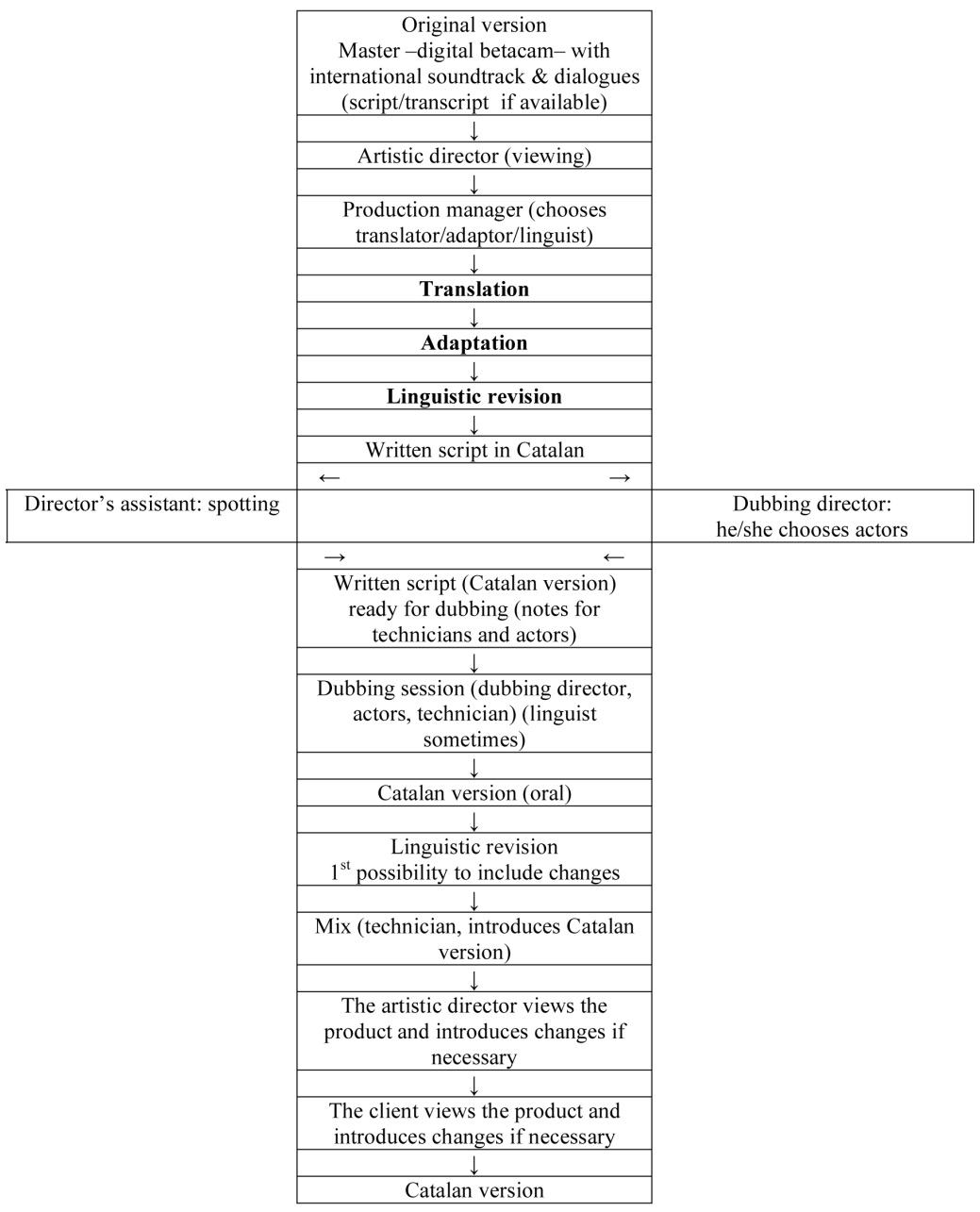

The translator is in charge of delivering a translation which expresses all the nuances of the original, taking into account its register, but without paying attention to lip-synchronisation. This does not imply that translators deny they are transferring an oral text into a written text which will be received as an audiovisual product: on the contrary, the relationship between the text and the image must be taken into account by the translator, who nonetheless will leave lip-synchronisation to the next professional in the chain.

The adaptor makes sure that the target language script is synchronised with the original length of the sentences (isochrony), the lip movement (lip-synch) and the body movements of the characters (kinetic synchrony). According to Gilabert, Ledesma and Trifol (2001), the adaptor must check the orality of the dialogues and adapt the translation if necessary. 
Finally, the linguistic revision is a step not always included in the working chain, but it is compulsory when working for Catalan television. Linguistic quality - meaning linguistic adequacy - is a key step for this network and this is why registered linguists, who have passed a selective examination, carry out a linguistic control at two different levels: they check that the written text does not include any mistakes and that the register is adequate, and they also guarantee that the oral version does not include any wrong or inconsistent pronunciations - often attributed to Spanish influences - and ask for a retake if necessary. In all cases, the linguist follows the client's indications: in the Catalan market, the client is generally the Catalan television and its style indications can be found in a recently created webpage. ${ }^{4}$

During this long process, some interjections may be added, changed or omitted, as shown in the following selection of examples from the three dubbed episodes. Changes generally occur during the adaptation and linguistic revision processes, but sometimes also during the recording session, although actors do not have the freedom to improvise as they do in original sitcoms. This might explain why their degree of orality - based solely on the number of interjections - differs.

\subsection{Interjections added in the adaptation/linguistic revision}

Table 6 presents examples of interjections which were added either during the adaptation or the linguistic revision. The table includes the original utterance, the written translation, the final written version and a back-translation of this latter version.

TABLE 6

Interjections added in the adaptation/linguistic revision

\begin{tabular}{|l|l|l|l|}
\hline Original & Translation & Final written version & Back-translation $^{4}$ \\
\hline $\begin{array}{l}\text { Um pollen? } \\
\text { (Coupling) }\end{array}$ & El pol.len? & A... el pol.len? & Um... pollen? \\
\hline $\begin{array}{l}\text { Well, the female lead. } \\
\text { Sorry. (Coupling) }\end{array}$ & $\begin{array}{l}\text { Protagonista } \\
\text { femenina. Perdona. }\end{array}$ & $\begin{array}{l}\text { Bé,/ protagonista } \\
\text { femenina./ Perdona. }\end{array}$ & $\begin{array}{l}\text { Well, the female lead. } \\
\text { Sorry. }\end{array}$ \\
\hline $\begin{array}{l}\text { Could you wrap it } \\
\text { up? (Normal) }\end{array}$ & $\begin{array}{l}\text { Que podries anar } \\
\text { per feina? }\end{array}$ & Fes via, sisplau. & Hurry up, please. \\
\hline $\begin{array}{l}\text { I will back your } \\
\text { proposal, Peyser. } \\
\text { (Working) }\end{array}$ & $\begin{array}{l}\text { Tiraré endavant la } \\
\text { seva proposta. }\end{array}$ & $\begin{array}{l}\text { Tiraré endavant la seva } \\
\text { proposta, entesos? }\end{array}$ & $\begin{array}{l}\text { I will back your } \\
\text { proposal, OK? }\end{array}$ \\
\hline
\end{tabular}

Most interjections added by the adaptor were already present in the original script, but were omitted by the translator. However, when adapting, the adaptor needed more text and used a feature which was already found in the original version. Interjections are especially useful due to their autonomy and brevity, and this is why they occupy an intonational unit. For example, the sentence Well, the female lead. Sorry. has clearly three different blocks ([well], [the female lead], [sorry]). The adaptor needs to fill the first block and the interjection bé fits perfectly there. On the other hand, there are instances where no interjection is included in the original but, in order to synchronise the text, the adaptor uses an interjection which not only accomplishes the synchrony requirements but also adds orality to the dubbed version. 


\subsection{Interjections changed in the adaptation/linguistic revision}

Table 7 focuses on the interjections which were changed either by the adaptor or the language consultant. The back-translation provides a literal translation for both the translation and for the final written version, which are separated by a slash.

TABLE 7

Interjections changed in the adaptation/linguistic revision

\begin{tabular}{|l|l|l|l|}
\hline Original & Translation & Final written version & $\begin{array}{l}\text { Literal back-transla- } \\
\text { tion }\end{array}$ \\
\hline Yes! (Coupling) & Ś́! & Visca! & [Yes!/Hooray!] \\
\hline $\begin{array}{l}\text { Oh, thank you. } \\
\text { (Normal) }\end{array}$ & Gràcies. & Moltes gràcies. & $\begin{array}{l}\text { [Thank you/Thank you } \\
\text { very much.] }\end{array}$ \\
\hline $\begin{array}{l}\text { Good God, woman, } \\
\text { you didn't call me in } \\
\text { the car about this? } \\
\text { (Working) }\end{array}$ & $\begin{array}{l}\text { Valga'm Déu } \\
\text { Senyor! Per què } \\
\text { no em trucaves } \\
\text { al mòbil? }\end{array}$ & $\begin{array}{l}\text { Mare meva! Per què } \\
\text { no em trucaves al } \\
\text { mòbil, dona? }\end{array}$ & $\begin{array}{l}\text { [God, my Lord, protect } \\
\text { me!/ My mother! } \text { Why } \\
\text { didn't you call me to } \\
\text { the cell phone? }\end{array}$ \\
\hline
\end{tabular}

In some cases, such as the first one, the changes are due to linguistic reasons: $\underline{\text { sí }}$ (literally yes) is considered a calque for the English expression yes and other interjections such as the proposed (visca) are preferred by the client. This strict linguistic control in Catalan dubbed products generally avoids errors which affect all type of pragmatic units such as discourse markers, discourse routines, speech rules, preformulated discourse and interjections (Gómez Capuz 2001), and which increasingly find their way into dubbed products (Castro 1997).

In other instances such as the second one, the changes are clearly due to reasons of isochrony (moltes gràcies is a longer utterance and therefore is closer to oh, thank you in terms of length than a simple gràcies, which would render the linguistic meaning more accurately). Although there is a slight change in the intensity of the interjection, the final effect is the same and this type of change is commonplace in dubbing.

As far as the last example is concerned, the second form is preferred probably due to the constraints of synchronisation. Although the literal translation of both Catalan interjections is completely different (Valga'm Déu Senyor > God, my Lord, protect me, and Mare meva $>$ My mother), the pragmatic value remains the same and, in my opinion, both options are valid. This is a good example which illustrates that

\footnotetext{
"translating interjections is not a matter of word translation," but "the translator must interpret the semantic and pragmatic meaning and the context of use, and then look for an equivalent (interjection or not) which can convey the same meaning and produce the same effect on the audience of the dubbed version" (Cuenca 2006).
}

\subsection{Interjections omitted in the adaptation/linguistic revision}

Some interjections included in the translated script do not find their way into the final written version, as shown in Table 8. 
TABLE 8

Interjections omitted in the adaptation/linguistic revision

\begin{tabular}{|l|l|l|l|}
\hline Original & Translation & Final written version & Back-translation \\
\hline $\begin{array}{l}\text { Well, I'm trying not to } \\
\text { answer before he } \\
\text { actually asks } \\
\text { (Coupling) }\end{array}$ & $\begin{array}{l}\text { Bé, intento no } \\
\text { contestar-li abans } \\
\text { que m'ho pregunti. }\end{array}$ & $\begin{array}{l}\text { Intento no contestar-li } \\
\text { abans que m'ho } \\
\text { pregunti. }\end{array}$ & $\begin{array}{l}\text { I'm trying not to } \\
\text { answer before he } \\
\text { actually asks. }\end{array}$ \\
\hline My God (Normal) & Ostres! & $(\mathrm{G})$ & (G) \\
\hline $\begin{array}{l}\text { Before lifting it, please } \\
\text { sign this (Working) }\end{array}$ & $\begin{array}{l}\text { Abans d'aixecar } \\
\text { res, sisplau... signi. }\end{array}$ & $\begin{array}{l}\text { Abans d'aixecar res, } \\
\text { m'hauria de signar } \\
\text { aquí }\end{array}$ & $\begin{array}{l}\text { Before lifting it, you } \\
\text { should sign here. }\end{array}$ \\
\hline
\end{tabular}

Again, some of the changes are due to the constraints of synchronisation - for example, My God is changed into a simple vocal sound because it is hardly heard in the original and two syllables do not fit - but in some cases the adaptation is due to the fact that other structures are preferred in certain contexts in Catalan: for example, although it is perfectly correct to use the interjection sisplau (please), it is also true that other structures such as m'hauria de... (you should; TVC 1997: 79) are more commonly used and sometimes forgotten in dubbed products because translators tend to mimic the syntactic patterns of the original.

Needless to say, an interjection is not always adequately rendered by another interjection in the target language, since each language has its own linguistic mechanisms. In our corpus, for example, $10.7 \%$ of interjections are not translated by interjective forms, but by means of other linguistic resources. For instance, the interjection well, translated by the Catalan equivalent bé in the first example, is omitted in the adapted version, following the indications of the Catalan television stylebook (TVC 1997: 79). This suggests that this unit does not need to be translated, especially when a long pause follows. However, this view is not shared by González and Sol (2002). In their analyses of the translation of well in the Catalan version of the film Pulp Fiction, they recommend translating it by any means possible, after stating that a third of the occurrences of the English well are not translated in the analysed film. In our opinion, a further analysis of the frequency of usage of both units should be carried out in order to establish their relationship and one should bear in mind that not all pragmatic units in the source language need to be rendered by pragmatic units in the target language. Indeed, a wide array of translation strategies are possible, such as the six identified by Cuenca (2006) after analysing the dubbed version of the film Four Weddings and a Funeral: (a) literal translation; (b) translation by using an interjection with dissimilar form but the same meaning; (c) translation by using a noninterjective structure with similar meaning; (d) translation by using an interjection with a different meaning; (e) omission, and (f) addition of elements, generally a primary interjection.

According to Cuenca (2006), strategy (b) is the most frequent when translating secondary interjections and seems to be the best option because it usually avoids the risk of pragmatic errors. Regarding primary interjections, Cuenca (2002b; 2004) used part of the same corpus in a previous analysis and concluded that they tend to be omitted or translated either by a different interjection with the same meaning or translated by strategy (b). 


\subsection{Interjections added during the recording}

Some changes also occur during the recording: table 9 shows some interjections added in the process, including the original, the final written version, the final oral version and a back-translation.

TABLE 9

Interjections added during the recording

\begin{tabular}{|l|l|l|l|}
\hline Original & Final written version & Final oral version & Back-translation \\
\hline $\begin{array}{l}\text { Well, that's sad, } \\
\text { because the funny } \\
\text { thing is is I think } \\
\text { we've both got a lot in } \\
\begin{array}{l}\text { common. I know I } \\
\text { have (Coupling) }\end{array}\end{array}$ & $\begin{array}{l}\text { Això és molt trist... } \\
\text { perquè el cas és... que } \\
\text { crec que tenim molt } \\
\text { en comú. Sé que jo sí. }\end{array}$ & $\begin{array}{l}\text { Mmm. Això és molt } \\
\text { trist... perquè el cas } \\
\text { és... que crec que } \\
\text { tenim molt en comú. } \\
\text { Sé que jo sí. }\end{array}$ & $\begin{array}{l}\text { Mmm. This is very } \\
\text { sad, because the thing } \\
\text { is I think we've both } \\
\text { got a lot in common. I } \\
\text { know I have. }\end{array}$ \\
\hline $\begin{array}{l}\text { Oh, darn. I'm out of } \\
\text { popcorn. I'll be right } \\
\text { back. (Normal) }\end{array}$ & $\begin{array}{l}\text { (G) Se m'han acabat } \\
\text { les crispetes }\end{array}$ & $\begin{array}{l}\text { Ah! Se m'han acabat } \\
\text { les crispetes }\end{array}$ & $\begin{array}{l}\text { Oh! I'm out of } \\
\text { popcorn. }\end{array}$ \\
\hline $\begin{array}{l}\text { Hello. (ININT) } \\
\text { (Working) }\end{array}$ & $\begin{array}{l}\text { (ADLIB) Hola. } \\
\text { ININT. }\end{array}$ & Bon dia. Hola. & Good morning. Hello. \\
\hline
\end{tabular}

In these cases interjections are added in basically two places: when there is a $(G)$ symbol or an (ADLIB) or an (AMBIENT) indications, when the actors are given the freedom to introduce vocalizations or expressions at random and when there is a space to be filled that had not been taken into account by the adaptor. The "G" symbol - meaning literally gesture - is used by adaptors to indicate to the actors that they must emit a sound that has no written form in Catalan (for example, a cough, a sneeze, clearing one's throat, etc.). The ADLIB and the AMBIENT indications mean that there is an unintelligible dialogue in the original soundtrack which has to be "filled" in the dubbed version: whereas in the AMBIENT characters are not defined and their mouth is not clearly visible (for example, supporters shouting at a football match), the ADLIB symbol is used when characters are more clearly visible (for example, additional dialogues in a restaurant).

\subsection{Interjections changed during the recording}

Table 10 presents the only interjection which was changed during the recording, providing the original version, the final written version, the final broadcast version and its back-translation.

TABLE 10

Interjections changed during the recording

\begin{tabular}{|l|l|l|l|}
\hline Original & Final written version & Final oral version & Back-translation \\
\hline $\begin{array}{l}\text { Oh, sure, yeah, } \\
\text { absolutely (Coupling) }\end{array}$ & Ah sí, sí, esclar. & Oh, sí, sí, esclar. & $\begin{array}{l}\text { Oh, yeah, yeah, } \\
\text { absolutely. }\end{array}$ \\
\hline
\end{tabular}

There was only one interjection changed during the recording in our corpus: the actor has imitated the original $o h$ and, instead of using the interjection $\underline{\text { ah }}$ proposed by the translator, has chosen another possible interjection in Catalan which is how- 
ever less appropriate in this particular context. In fact, Cuenca (2006) considers that the written form oh exists, with different pronunciations, in English, Catalan and Spanish, "and it exhibits similar expressive meanings. However, its frequency and context of use are different and the literal translation of the form leads to pragmatic errors." Another short analysis of the translation of oh in three different Spanish translations of the American film Pulp Fiction is also found in Chaume (2004), who considers these units to be used in repair strategies, in question-answer adjacency pairs and as intensifiers and also states that the same written form does not convey the same pragmatic meaning in all languages.

\subsection{Interjections omitted during the recording}

Table 11 presents an example of an interjection omitted during the recording, which corresponds to the series Coupling.

TABLE 11

Interjections omitted during the recording

\begin{tabular}{|l|l|l|l|}
\hline Original & Final written version & Final oral version & Back-translation \\
\hline $\begin{array}{l}\text { Oh, Patrick, Patrick, } \\
\text { Patrick (Coupling) }\end{array}$ & Oh, Patrick, Patrick, & Patrick, Patrick, & Patrick, Patrick, \\
Patrick & Patrick & Patrick \\
\hline
\end{tabular}

In this particular case the actress has omitted the interjection oh, probably due to a slip, because it is obvious that the final written version fits perfectly in the original space available.

Table 12 summarizes the data related to the changes observed in the three dubbed sitcoms (Coupling, Normal Ohio and Working). Seven scenarios are envisaged for each sitcom: interjections are the same (that is, they are found in the translation and are maintained in the final broadcast version), interjections are added/changed/omitted in the written text (that is, in the adapted and linguistically revised written version given to the actors), and interjections are added/changed/ omitted during the recording (that is, actors improvise and modify the written text). The number of interjections for each situation is provided next to a percentage which is calculated taking into account the total number of interjections for each sitcom. For example, 87 interjections out of 120 are kept the same in the sitcom Normal Ohio, and this corresponds to a $72.50 \%$

TABLE 12

Distribution of change types in the dubbing process

\begin{tabular}{|l|l|l|l|l|l|l|}
\hline Interjections are... & \multicolumn{2}{|c|}{ Coupling } & \multicolumn{2}{c|}{ Normal } & \multicolumn{2}{c|}{ Working } \\
\hline ...the same & 86 & $72.26 \%$ & 87 & $72.50 \%$ & 41 & $54.67 \%$ \\
\hline ...added in the written text & 16 & $13.44 \%$ & 12 & $10.00 \%$ & 20 & $26.67 \%$ \\
\hline ...changed in the written text & 4 & $3.37 \%$ & 8 & $6.67 \%$ & 9 & $12.00 \%$ \\
\hline ...omitted in the written text & 4 & $3.37 \%$ & 9 & $7.50 \%$ & 4 & $5.33 \%$ \\
\hline ...added during the recording & 2 & $1.68 \%$ & 4 & $3.33 \%$ & 1 & $1.33 \%$ \\
\hline ...changed during the recording & 1 & $0.84 \%$ & 0 & $0.00 \%$ & 0 & $0.00 \%$ \\
\hline ...omitted during the recording & 6 & $5.04 \%$ & 0 & $0.00 \%$ & 0 & $0.00 \%$ \\
\hline
\end{tabular}


In short, the data show that in dubbing most changes occur during the written processes (adaptation and linguistic revision) and are added to the translation: despite the fact that a percentage of $54.67 \%$ to $72.5 \%$ of interjections originally proposed by the translator are kept, a remarkable percentage are added (from $10 \%$ to $26.67 \%$, depending on the sitcom) and a few are changed (from $3.37 \%$ to $12 \%$ ) or omitted (from $3.37 \%$ to $7.5 \%$ ). Furthermore, and contrary to the sitcoms originally shot in Catalan, actors are not given the freedom to improvise during the recording. Therefore, very few interjections are added, changed or omitted during the recording, with percentages under $5 \%$ in all cases.

\section{Concluding remarks}

In conclusion, the differences in the number and proportion of interjections, which are key oral elements, have been analysed in dubbed and original sitcoms. Although attempting to mimic spontaneous oral language, the language of dubbing is nothing but a convention, an artificial linguistic variety which takes elements from different sources to create a credible yet planned spontaneous language with no room for continuous improvisations, whereas Catalan sitcoms include more spontaneous interjections, even units not sanctioned by the prescriptive authorities, therefore increasing the orality.

Should translators bridge the gap and offer translations closer to real oral language even though they might contain units not sanctioned by the prescriptive authorities? Should the language of dubbed sitcoms and the language of original sitcoms draw closer, as Ainaud et al. (2001: 133-138) suggest? In our opinion, there is no doubt that translators should aim at recreating a colloquial spontaneous language, but putting the language of both types of products on the same level is nothing but a fallacy: the dubbing process has its own specific constraints, as demonstrated in section 5, and is part of a global fiction in which everything - characters, settings, language, etc. - is a simulated reality more distant to the Catalan audience than the one portrayed by Catalan sitcoms.

In the second part of the article, an analysis of the changes that the translation undergoes during the process has been performed, illustrated by the description of a single type of unit. The data presented show that all audiovisual translations are part of a dynamic process in which various agents participate in order to shape a final version.

While this article provides some answers regarding the presence of interjections in sitcoms, it should be considered as a first step of a wider research on the orality of the language resulting from the dubbing process, in which various features of orality could be analysed, as shown by Romero (2006a; 2006b) in Spanish.

\section{NOTES}

1. The data is taken from a Ph.D. thesis developed within the doctoral programme in Applied Linguistics at the Universitat Pompeu Fabra (Barcelona) in which an audiovisual corpus of sitcoms was created in order to analyse interjections from various perspectives and propose a lexicographical tool (Matamala 2005a; Matamala and Lorente 2008).

2. The corpus was created by the author specifically for her doctoral dissertation because no corpora of this type existed in the language combination English > Catalan. This corpus was created with 
humble technological means and is rather small in size - nothing in comparison with Forlixt 1 , for example (Valentini 2008; Heiss and Soffritti 2008) -, but hopefully it will be enlarged. However, it has been one of the first of its kind and can be used to provide trends which in the future can be validated in wider corpora.

3. Unfortunately, a question not answered yet, due to the complexity of the work involved with an oral spontaneous corpus, is whether English oral language features less interjections than Catalan. The answer might be obtained by analysing real spontaneous oral corpora. This would provide an insight regarding the specificity of interjection usage in both languages.

4. See $<$ http://esadir.cat/ $>$, visited on June $6^{\text {th }}, 2009$.

\section{REFERENCES}

Aijmer, Karin (2002): English Discourse Particles. Evidence from a Corpus. Amsterdam: John Benjamins.

Ainaud, Jordi, Espunya, Anna and Pujol, Dídac (2003): Manual de traducció anglès-català. Vic: Eumo.

AмекA, Felix (1992) Interjections: The universal yet neglected part of speech. Journal of Pragmatics. 18(2-3):101-118.

Andersen, Gisle (2001): Pragmatic Markers and Sociolinguistic Variation. A Relevance-theoretic Approach to the Language of Adolescents. Amsterdam: John Benjamins.

Brinton, Laurel J (1996): Pragmatic Markers in English. Grammaticalization and Discourse Function. Berlin: Mouton de Gruyter.

Calsamiglia, Helena and Tusón, Amparo (1999): Las cosas del decir. Manual de análisis del discurso. Barcelona: Ariel.

Castellà, Josep Maria (2004): La complexitat lingüística en el discurs oral i escrit: densitat lèxica, composició original i connexió textual. Tesis doctorals en xarxa, Institut Universitari de Lingüística Aplicada, Universitat Pompeu Fabra. Visited on May 11 ${ }^{\text {th }}, 2009$, $<$ http://www.tdcat.cesca.es/TDX-0311102-134928/index.html>.

CAstro, Xosé (1997): Sobre la traducción de guiones para la televisión en España. Visited on May $11^{\text {th }}, 2009,<$ http://www.xcastro.com/peliculas.html >.

Chaume, Frederic (2003): Doblatge i subtitulació per a la TV. Vic: Eumo.

Chaume, Frederic (2004): Discourse markers in audiovisual translating. Meta. 49(4):843-855.

Chin ro, Delia (2005): Suspension of disbelief or mediatic diglosia? How Italians perceive dubbese. Paper presented at the International Conference Challenges of Multidimensional Translation. Saarbrücken.

Crystal, David and Quirk, Randolph (1964): Systems of Prosodic and Paralinguistic Features in English. The Hague: Mouton de Gruyter.

Crystal, David and Quirk, Randolph (1985): A Comprehensive Grammar of the English Language. London: Longman.

Cuenca, Maria Josep (1996): Sintaxi fonamental. Les categories gramaticals. Barcelona: Empúries.

Cuenca, Maria Josep (2000): Defining the indefinable? Interjections. Syntaxis. An International Journal of Syntactic Research. 3:29-44.

Cuenca, Maria Josep (2002a): Els connectors textuals i les interjeccions. In: Joan Solà, Maria Rosa Lloret, Joan Mascaró and Manuel Pérez Saldanya, eds. Gramàtica del català contemporani. Barcelona: Empúries, 3173-3237.

Cuenca, Maria Josep (2002b): Translating interjections for dubbing. In: Studies in Contrastive Linguistics. Proceedings of the $2^{\text {nd }}$ International Contrastive Linguistics Conference. October 2001 Santiago de Compostela: Servicio de Publicacións e Intercambio Científico, Universidade de Santiago de Compostela, 299-310.

Cuenca, Maria Josep (2004): Translating interjections: an approach from grammaticalization theory. In: Augusto Soares da Silva, ed. Linguagem, Cultura e Cognição: Estudos de Lingüística Cognitiva. Coimbra: Almedina, 325-345. 
Cuenca, Maria Josep (2006): Interjections and pragmatic errors in dubbing. Meta. 51(1):20-35.

De Yzaguirre, Lluís, Garcia, Yannick, Matamala, Anna and Ribas, Marta (2005): Tratamiento informático de un corpus de guiones y traducciones de textos audiovisuales: implicaciones en traductología. In: Patrick Zabalbeascoa, Laura Santamaria and Frederic Chaume, eds. La traducción audiovisual. Investigación, enseñanza y profesión. Granada: Comares, 107-113.

Espuny, Janina (1998): Aspectes de la interferència lèxica castellana en el discurs oral català. In: Lluís Payrató, ed. Oralment. Estudis de variació funcional. Barcelona: Publicacions de l'Abadia de Monsterrat, 276-290.

Fischer, Kerstin(2000): From Cognitive Semantics to Lexical Pragmatics. The Functional Polysemy of Discourse Particles. Berlin: Mouton de Gruyter.

Fraser, Bruce (1990): An approach to discourse markers. Journal of Pragmatics. 14(6):383395.

Fraser, Bruce (1999): What are discourse markers? Journal of Pragmatics. 31(7):931-952.

Fuentes Morán, Teresa (1995): Die Grammatik des Spanischen in zweisprachigen Wörterbüchern des Sprachenpaares Spanish-Deutsch für Deutschprachige. Augsburg: Lexicographica.

Gilabert, Anna, Ledesma, Iolanda and Trifol, Albert (2001): La sincronización y adaptación de guiones cinematográficos. In: Miguel Duro, ed. La traducción para doblaje y subtitulación. Madrid: Cátedra (Signo e Imagen), 325-330.

Goffman, Erving (1981): Response cries. In: Erving Goffman. Forms of talk. Oxford: Blackwell, $78-122$.

Gómez Capuz, Juan (2001): La interferencia pragmática del inglés sobre el español en doblajes, telecomedias y lenguaje coloquial: una aportación al estudio del cambio lingüístico en curso. Tonos digital. 2, Visited on May 1 ${ }^{\text {th }}, 2009$, <www.tonosdigital.com $>$.

GonZÁlez, Montserrat (1998): Bé i bueno. Apunts sobre l'ús dels marcadors discursius. In: Lluís Payrató, ed. Oralment. Estudis de variació funcional. Barcelona: Publicacions de l'Abadia de Montserrat, 241-257.

GonZÁlez, Montserrat (2001): Els marcadors pragmàtics compostos en el relat oral anglès i català. Caplletra. 30:73-94.

GonzÁlez, Montserrat and Sol, Usoa (2002): 'Well' or the pragmatic of translation. 28th International AEDEAN Conference, December 16-18, 2004, València.

Greenbaum, Sidney and Quirk, Randolph 1990): A Student's Grammar of the English Language. Essex: Longman.

Heiss, Christine and Soffritti, Marcello (2008) Forlixt 1 - The Forlì Corpus of Screen Translation. Exploring Microstructures. In: Delia Chiaro, Christine Heiss and Chiara Bucaria, eds. Between Text and Image. Updating research in Screen Translation. Amsterdam: Benjamins, 51-62.

Hopper, Paul J and Trauggot, Elizabeth Close (2003): Grammaticalization. Cambridge: CUP. Huddleston, Rodney (1986): Introduction to the Grammar of English. Cambridge: Cambridge University Press.

Jаковson, Roman (1960): Linguistics and poetics. In: ThomasA. Seвeor, ed. Style in language. Cambridge: MIT Press, 340-377.

James, Deborah (1973): The Syntax and Semantics of Some English Interjections. Unpublished $\mathrm{PhD}$ dissertation. University of Michigan, Michigan.

Kerbrat-Orecchioni, Catherine (1990): Les interactions verbales I, II, III. Paris: Colin.

Kerbrat-Orecchioni, Catherine (1996): La conversation. Paris: Seuil.

Kleiber, Georges (1990): La sémantique du prototype. Catégories et sens lexical. Paris: PUF.

Laviosa, Sara (2003): Corpora and the translator. In: Harold Somers, ed. Computers and Translation. A translator's guide. Amsterdam: John Benjamins, 105-117.

Ledesma, Iolanda and López, Mercè (2002): El doblatge. In: II Seminari de Correcció de Textos. La qualitat de la llengua oral en els mitjans de comunicació. Barcelona: IEC.

Leech, Geoffrey and Svartvik, Jan (1975): A Communicative Grammar of English. London: Longman. 
Lehmann, Christian (1995): Thoughts on Grammaticalization. Munich: Lincom Europa.

Lorente, Mercè (2002): Altres elements lèxics. In: Joan Solà, Maria Rosa Lloret, Joan MasCaró and Manuel Pérez Saldanya, eds. Gramàtica del català contemporani. Barcelona: Empúries, 831-888.

Martí, Jaume (1997): Les sèries de producció pròpia. In: Margarida Bassols, Albert Rico and Anna Maria Torrent, eds. La llengua de TV3. Barcelona:Empúries, 73-84.

Matamala, Anna (2001): Les interjeccions al diccionari. Teoria, anàlisi i primera proposta de representació lexicogràfica. Unpublished M.A. thesis, Universitat Pompeu Fabra, Barcelona.

Matamala, Anna (2005a): Les interjeccions en un corpus audiovisual. Descripció i representació lexicogràfica. Barcelona: IULA. Also published online: Tesis Doctorals en Xarxa: $<$ http://www.tdx.cesca.es/TDX-1003105-130347>.

Matamala, Anna (2005b): Converses espontànies o converses prefabricades? Les interjeccions en comèdies de situació catalanes i doblades. Estudios Catalanes. 3:65-77.

Matamala, Anna and Lorente, Mercè (2008): New tools for translators: INTCA, an electronic dictionary of interjections. In: Delia Chiaro, Christine Heiss and Chiara Bucaria, eds. Between Text and Image. Amsterdam: Benjamins, 63-75.

Olohan, Maeve. (2004): Introducing Corpora in Translation Studies. London: Routledge.

Paloma, David and Segarra, Mila (2000): Llengua oral i llengua escrita a les sèries de televisió." In: Anna Cros, Mila Segarra and Anna Maria Torrent, eds. Llengua oral i llengua escrita a la televisió. Barcelona: Publicacions de l'Abadia de Montserrat, 49-73.

Payrató, Lluís and Alturo, Núria, eds. (2002): Corpus oral de conversa col-loquial. Materials de treball. Barcelona: Publicacions de la Universitat de Barcelona.

Poyatos, Fernando (1993): Paralanguage. A Linguistic and Interdisciplinary Approach to Interactive Speech and Sound. Amsterdam: John Benjamins.

QuiRk, Randolph et al. (1972): A Grammar of Contemporary English. London: Longman.

REDEKER, Gisele (1990): Ideational and pragmatic markers of discourse structure. Journal of Pragmatics. 14(3):367-381.

Romero, Pablo (2006a) Close Friends? A study of the idiomaticity of the Spanish dubbing language. Paper delivered at the Euroconference 2006. Copenhaguen, 1-5 May 2006.

Romero, Pablo (2006b): The Spanish Dubbese - A case of (un)idiomatic Friends. Jostrans. 6. Visited on May 11 ${ }^{\text {th }}, 2009$, <http://www.jostrans.org/issue06/art_romero_fresco.php>.

SAncho, Pelegrí (1999): Introducció a la fraseologia. Aplicació al valencià colloquial. València: Denes.

Schiffrin, Deborah (1987): Discourse Markers. Cambridge: Cambridge University Press.

Schourup, Lawrence (1982): Common Discourse Particles in English Conversation. Ohio: Ohio State University.

TAYlor, John R (1989): Linguistic Categorization: Prototypes in Linguistic Theory. Oxford: Clarendon Press.

Trager, George (1958): Paralanguage: a first approximation. Studies in Linguitsics. 13(1), 1-12.

Trauggot, Elizabeth Close (1995): Subjectification in grammaticalization. In: Susan Wright and Dieter SteIn, eds. Subjectivity and Subjectivization. Cambridge: CUP, 31/54.

Trauggot, Elizabeth Close and Heine, Bernd, eds. (1991): Approaches to Grammaticalization. Amsterdam: John Benjamins.

Tusón, Amparo (1995): Anàlisi de la conversa. Barcelona: Empúries.

TVC. (1997): Criteris lingüistics sobre traducció i doblatge. Barcelona: Edicions 62.

Ungerer, Friedrich and Schmid, Hans-Jorg (1996) An Introduction to Cognitive Linguistics. London: Longman.

Valentini, Cristina (2008): Forlixt 1- The Forlì Corpus of Screen Translation. Exploring macrostructures. In: Delia Chiaro, Christine Heiss and Chiara Bucaria (eds.) Between Text and Image. Updating research in screen translation. Amsterdam: Benjamins, 37-50. 
502 MetA, LIV, 3, 2009

Vila, Xavier (1998): Bueno, vale ja de criticar, no? Marques transcòdiques lèxiques i variació funcional en català. In: Lluis Payrató, ed. Oralment. Estudis de variació funcional. Barcelona: Publicacions de l'Abadia de Montserrat, 259-273.

Wierzbicka, Anna (1992): The semantics of interjections. Journal of Pragmatics. 18(2-3):159-192. Wilkins, David P. (1992): Interjections as deictics. Journal of Pragmatics. 18(2-3):119-158. 